\title{
JOSEPH NENG SHUN KWONG: A FAMOUS AND OBSCURE SCIENTIST
}

\author{
Simón Reif-Acherman \\ Escuela de Ingeniería Química, Universidad del Valle, A. A. 25360 Unicentro, Cali - Colombia
}

Recebido em 7/9/07; aceito em 22/4/08; publicado na web em 3/10/08

\begin{abstract}
Many students and professionals in chemistry and chemical engineering related the name Kwong with one of the most remarkable equations of state with two parameters. In the same way, very few people know who Kowng was. This article shows some of the unknown personal and professional facts of Joseph Neng Shun Kwong, a person who devoted almost four decades of his life to the industrial research in the adhesives industry.
\end{abstract}

Keywords: Physical chemistry; thermodynamics; adhesives.

\section{INTRODUCTION}

The names of Redlich and Kwong are widely known among chemists and chemical engineers for their co-authored equation of state. While some information is known about Redlich because of his academic activities, practically nothing is told about Kwong. This article will try to show concisely the most outstanding facts in the life of Joseph Neng Shun Kwong, a modest man, with many remarkable achievements in an industrial career lasting almost four decades.

Joseph Neng Shun Kwong (Figure 1) was born in Chung Won, China, on October 28, 1916, the oldest of the seven siblings (one boy and 6 sisters) that survived to adulthood. When he was about 7 years old, the family moved to the United States, where his father would study optometry. When his father returned to China after completing his training, Kwong stayed in Sacramento, California, with his Grandfather, who had immigrated to the U.S. in 1888 and built up a fruit and vegetable store. Kwong began his education at Sacramento High School, and continued at Sacramento Junior College for the next two years, and at the University of California one year more.

Kwong received his Bachelor of Arts (B.A.) degree from Stanford University in 1937 in Chemistry and Basic Medical Sciences, ranking in the top five in his class. He was granted his Master of Science in Chemical and Metallurgical Engineering, with emphasis on unit operations, at the University of Michigan in October, 1939 and got his $\mathrm{Ph} . \mathrm{D}$ in Chemical Engineering, with a minor in Physical Chemistry, at the University of Minnesota in $1942 .{ }^{2}$ His doctoral dissertation was on "Surface and energy relationship in crushing of minerals", with Professor Edgar Lambert Piret (1910-1987) as his major adviser. The purpose of this research was to confirm the relationship of direct proportionality between the new surface formed with the crushing of some solid materials and the energy input, and trying to develop the basic information then required in this field. The results of this research were presented in a paper published only some years later. ${ }^{3}$ He became a licensed Professional Engineer in both California and Minnesota Universities (1952).

\section{A LOT MORE THAN ONE EQUATION}

Kwong's first professional experience was at Minnesota Mining and Manufacturing Co. (later 3M), where he was a chemical engineer in adhesive products between 1942 and 1944. This was a period in the

*e-mail: sireache@univalle.edu.co

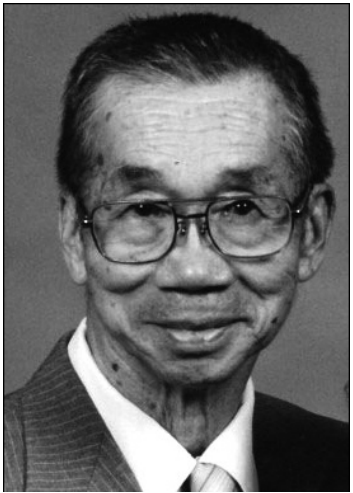

Figure 1. Joseph Neng Shun Kwong (age 75, July, 1992). Courtesy of Kwong's family

history of the company, when the main interests were the development of different applications of cellophane tapes (pressure sensitive, transparent, moisture proof material with adhesive) complemented with the production of defense materials for World War II, and other types of tapes for different uses. Kwong's research work was in the process area, mainly related to esterification, emulsification, and monomer synthesis and purification. ${ }^{4}$ Kwong was the first non-white professional hired by the company. Very probably the knowledge that Joseph Kugler, his first manager at 3M, had about him from his university days, and the high scientific reputation of his adviser Piret and his services as a consultant to the company over two decades, had some influence on the Kwong's recruitment.

In 1944, one year before his naturalization as an American citizen, Kwong joined Shell Development Co, at Emeryville, California. There, he had the opportunity to work in different professional areas. For the first five years, his main research was as a Chemist, as well as a Physical Chemist, being project leader for a group of up to eight persons. They worked in the development, construction and operation of pilot plant units for continuous esterification, pre-polymer extraction, and monomer purification. It was during this period that Kwong met the Jewish Austrian chemist Otto Redlich (1896-1978). Redlich had emigrated to the United States in 1938 after lose his job at the Vienna University of Technology because of the implementation at his country of some laws that restricted the academic activities to Jewish people, and had joined Shell 7 years later, after leaving the Washington State College (where he was an Associated Researcher). ${ }^{5}$ Besides other subjects, Redlich showed great interest in carrying out research on the thermo- 
dynamics of solutions. Although there doesn't seem to be evidence of Kwong's professional inclinations in this area of science, the fact is that in September, 1948 they presented a joint paper on a new equation of state at the Symposium on Thermodynamics and Molecular Structure of Solutions, held as a part of the 14th Meeting of the American Chemical Society at Portland, Oregon, which was subsequently published in February, $1949 .{ }^{6}$ The research was very probably related with their common activities at Shell, and the need of the establishment of a simple algebraic relation for the precise representation of experimental volumetric data of those compounds, mainly hydrocarbons, involved in the different Company's processes, which allowed the calculation of the respective fugacities. The new equation,

$P=\frac{R T}{v-b}-\frac{a}{T^{0.5} v(v+b)}$

where $P, v$, and $T$, represent the pressure, molar volume, and temperature, respectively, while $a$ and $b$ are specific parameters for each fluid, did not immediately receive the recognition which it deserved. Only almost two decades later did it begin to be appreciated that it was accurate enough to use relative to other equations which had a greater number of constants. Even taking into consideration its limitations (which are mainly due to its empirical nature which, consequently, doesn't allow it to provide rigorous results and thermodynamic consistency) and its own derivation for non-polar (or slightly polar) substances and their mixtures (it is not advisable to use it for compounds forming hydrogen bonds), it is still considered one of the two best two-constant equations ever published. Together with the equation developed by D. Y. Peng and D. B. Robinson in $1976,{ }^{7}$ the original Redlich-Kwong equation of state provides the best third-degree expression among the two constant relationships and is one of the most widely used equations of state in industry for correlating vapor-liquid equilibrium and volumetric and thermodynamic properties of pure substances and their mixtures in the gaseous phase. The equation is still widely embedded in software and used by researchers and students for prediction of volumetric and thermodynamic properties, design and optimization of process equipments, and reservoir simulation.

It seems that Kwong never again took up the theoretical aspects of thermodynamics. His activities in the last year at Shell were, instead, mainly in the areas of economic evaluations and process and engineering design. In 1951 he returned to 3M, in Saint Paul, as a Senior Chemical Engineer in the Chemical Division. He was initially assigned to a project to economically evaluate the propionic acid route to acrylic acid. Kwong came to the conclusion that the best alternative was the acrylonitrile route, a suggestion that once, it was implemented by the Company, resulted in a multimillion dollar saving and profits for 16 years. ${ }^{4}$

This was not the only time that his investigations contributed to the profits of the 3M Company. His research work on epoxy resins and fluorinated materials, which began in the 50's and continued as long as he worked there, brought substantial profits to $3 \mathrm{M}$ as well. The patents resulting from this research were concerned with the making of thermosetting epoxy resin compositions and the cured resinous products obtained thereby involving different alternatives in accord with their specific uses. ${ }^{8}$ The obtained products proved to be useful for the impregnation of strands of glass filaments which were formed into webs for the manufacture of laminates, as casting resins, plasticizers, adhesives, sealants, and heat-resistant products, or for encapsulating electrical products. The sales of these products, even after two decades, led to production of materials which exceeded several millions pounds of product a year.

In 1956 Kwong was promoted to the position of Chemical Engineer Specialist. His abilities were so recognized in the Company, that his contributions began to cover technical fields different than those in which he was officially involved. This was the case, for example, when there was a need for new large stills with strict specifications in pressure and temperature for acrylate monomer purification. Although the Chemical Production Department had its own engineering department, in recognition of his skills in this area, the Department asked him to design the necessary bubble cap columns. ${ }^{9} \mathrm{He}$ also worked on projects in the Central Research and Chemolite groups. Throughout his life he continued his professional development in many areas including coursework in computer programming, advanced polymer chemistry, and business finance.

In 1970 Kwong was assigned to the Film \& Allied Products Division of $3 \mathrm{M}$. The nature of his activities changed from being mostly lab and pilot plant process product development with tangible results to having results more intangible in nature. The projects in which he took part in the course of the ten years he was there included studies of the organic volatiles in polyester resins, on catalyst and stabilization agents in polyester resins, on the rheological behavior and hydrolytic and thermal stabilities of some products, and investigations on the influence of extractable and volatile oligomers on the qualities of the produced films, to cite only a few subjects. One of the Kwong's supervisors at $3 \mathrm{M}$ cited Kwong's study of the moisture content in polyester resins on their properties as a very good example showing one of the most characteristic and distinctive aspects of his method of working: he discovered most of the problems he worked on. For a long time from the beginning of resin production, no provision had been made at the Film Division to keep the polyester resin dry after it was produced. Worried about the possibility that the water content of the resin could influence its properties, Kwong carried out studies by which he showed the need to install a dryer ahead of the film extruder to prevent any degradation of the resin during the extrusion process, and thus improved the products' yield. ${ }^{9}$

Joseph N. S. Kwong retired from 3M at age 64 in 1980 as a Product Development Specialist, when the company offered him a "buy out" package. He was recognized later by both the American Chemical Society (ACS) and the American Institute for Chemical Engineers (AIChE) for more than 50 years of participation in each professional organization (Figure 2). On January 4, 1998 he died of pneumonia at the Lyngblomsten Care Center in Saint Paul, Minnesota. ${ }^{10}$

\section{A MAN WITH MANY VIRTUES}

Joe, as his friends knew him, was a special research person in several ways. His workmates at $3 \mathrm{M}$, the company which he served for 33 years, remember him for his independence, perseverance and thoroughness. According to them, Kwong was one of those men that were quite persistent, gave a lot of thought to all what he was doing, and tended to do a very thorough well planned, complete job, and with detailed reports. These qualities earned him in the compliments of his superiors, both at $3 \mathrm{M}$ and Shell. He also helped mentor and develop many younger staff, particularly minorities, throughout his career.

The Kwong's family was composed of his wife Mary Gin (born in the United States) who he got married in 1942, and their three sons, Gary, Roger, and Arnold (Figure 3). When he wasn't working, Kwong busied himself with family summer vacation trips, with $\mathrm{Cub}$ and Boy Scouting activities, photography, gardening, investing in the stock market, and handyman work. His work in the community for schools, his church, and local government covered decades. As for many of Minnesota's inhabitants, the family has had a second home since 1959 on the shore of one of the about 15,000 Minnesota lakes where he liked to go fishing. His family always remembers him as a person with a strong sense of humor, a good smile, somebody who wasn't looking to promote himself, and who liked that his achievements stood for themselves. 


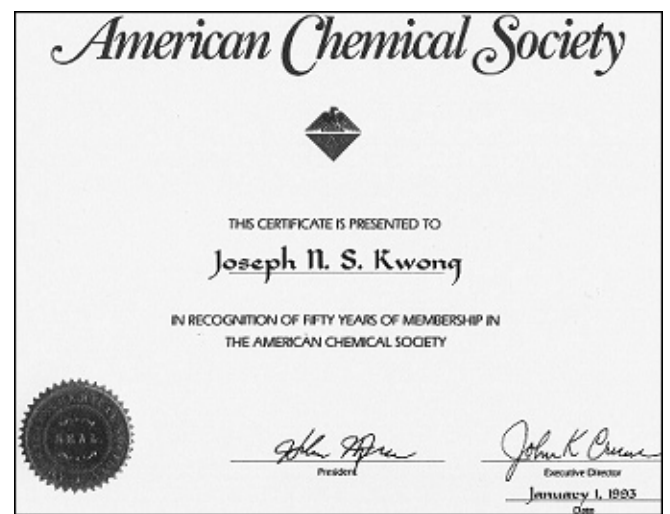

Figure 2. American Chemical Society's certificate of recognition for fifty years of membership (January 1, 1993). Courtesy of Kwong's family

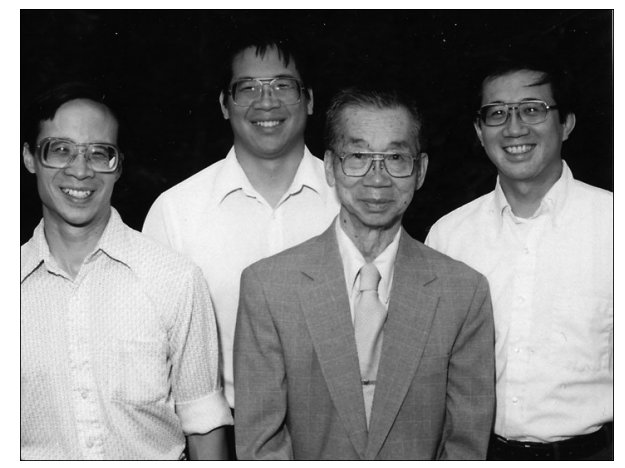

Figure 3. Joseph Neng Shun Kwong with his three sons - left to right, Gary, Arnold, Roger-(July, 1992). Courtesy of Kwong's family

\section{CONCLUSIONS}

Kwong was essentially a researcher, with special emphasis in those subjects that had practical application. The equation of state was his only contribution in the academic field. He was never interested in pursuing an academic career, whether teaching or doing research in a university setting. Even if he had like it, he would have found great difficulties due to racial discrimination in most of the American universities (the first racial minority chemistry assistant professor at the University of Minnesota, for example, was not hired until after 1967, about 45 years after Kwong finished his doctorate studies). His personal approach to research and employment in industry were shaped by an understanding that he felt more comfortable working with others (including mentoring them, especially if they were Asian immigrants) while being a competent, persistent researcher than in supervising them. He turned down at least one opportunity to become a supervisor while at $3 \mathrm{M}$. He felt that his family and community work were more important than the probable need to spend significantly more time at work if he was in a management role. $\mathrm{He}$ cared more about doing a good job in his own view than in working for recognition or personal power.

Only in the first quarter of a century after its publication date, at least thirty-three attempts had been suggested in order to improve the accuracy of the Redlich-Kwong equation of state by introducing new parameters, which nevertheless affected its advantage of simplicity. ${ }^{11}$ Its original applications in the calculation of volumetric relations and fugacity coefficients, have extended to successfully cover through derived expressions other variables such compressibility factors, enthalpies, entropies, heat capacities, etc., for single and multicomponent systems. A recent review on the progress on developing equations of state still consider the expression as perhaps, the most important model for the modification for the van der Waals equation of state. ${ }^{12}$ It also emphasizes the accurateness and easiness of its representation of volumetric properties, the requirement of the fewest number of properties (critical pressure and temperature, and acentric factor) for the calculation of the generalized parameters $a$ and $b$, and the little computer time required for obtain good results as its main advantages. Other works present the Soave's modification ${ }^{13}$ to the original equation as a still very useful predictive model for the vapor-liquid equilibrium calculations, mainly for non-polar compounds. ${ }^{14} \mathrm{~A}$ look to the results analysis of the number of citations in a search in the Web of Science in the period between 2000 and January 2008 gives a good idea on the impact of the equation: ${ }^{15} 351$ out of a whole of 1681 citations (approximately a fifth part) on equations of state deal with, or at least index, the Redlich-Kowng equation. The great importance his equation still has in both, teaching and practical aspects, is very probably the most evident legacy of this famous and a now a little less obscure scientist.

\section{ACKNOWLEDGMENTS}

I am indebted to Joseph N. S. Kwong's wife, Mary, and the oldest of their three sons, Gary, for their great collaboration and kindness with this project. I thank also A. Kwong for help me to get publication-quality photographs of his father and additional facts about his life, the late Kwong's workmate, W. Lundquist, for his personal comments, and Mrs. G. Baysinger, T. Hebron, and K. Klinkenberg, at the Swain Library of Chemistry \& Chemical Engineering in the Stanford University, Bentley Historical Library of the University of Michigan, and University of Minnesota Archives, respectively, for information about the Kwong's studies in each one of these academic institutions.

\section{REFERENCES AND NOTES}

1. Kwong, M.; Kwong, G.; Kwong, A.; personal communication.

2. Register of Ph.D. Degrees conferred by the University of Minnesota (1938 - June, 1956).

3. Kwong, J. N. S.; Adams, J. T., Jr.; Johnson, J. F.; Piret, E. L.; Chem. Eng. Prog. 1949, 45, 508.

4. There are not registers at the 3M's archives about his professional activities there. All the information included in this article was taken from an unpublished document, Personal summary of activities, 19421980, written by Kwong himself.

5. Reif-Acherman, S.; Quim. Nova, in press.

6. Redlich, O.; Kwong, J. N. S.; Chem. Rev. 1949, 44, 233.

7. Peng, D.-Y.; Robinson, D. B.; Ind. Eng. Chem. Fundam. 1976, 15, 59.

8. Kwong, J. N. S.; GB pat. 875,073 1956; US pat. 3,257,342 1966; US pat. 3,523,143 $\mathbf{1 9 7 0 .}$

9. Lundquist, W.; personal communication.

10. Shah, A.; Star Tribune, Jan 8, 1998, B6.

11. Horvath, A. L.; Chem.Eng.Sci. 1974, 29, 1334.

12. Wei, Y. S.; Sadus, R. J.; AIChE J 2000, 46, 169.

13. Soave, G. S.; Chem. Eng. Sci. 1972, 27, 1197.

14. Poling, B. E.; Prausnitz, J. M.; O’Connell, J. P.; The properties of gases and liquids, $2^{\text {nd }}$ ed., McGraw-Hill: New York, 2000; Anderko, A. In Equations of state for fluids and fluid mixtures. Part I; Sengers, J. V.; Kayser, R. F.; Peters, C. J.; White, H. J., Jr. eds.; Elsevier: Amsterdam, 2000, ch. 4.

15. http://portal.isiknowledge.com/portal.cgi?DestApp=WOS\&Func=Frame, accessed in January 2008. 